\title{
Optimization of River Water Quality Surveys by Multivariate Analysis of Physicochemical, Bacteriological and Ecotoxicological Data
}

Ana I. Gomes \& José C. M. Pires \& Sónia A. Figueiredo \&

Rui A. R. Boaventura

\begin{abstract}
This study aims to optimize the water quality monitoring of a polluted watercourse (Leça River, Portugal) through the principal component analysis (PCA) and cluster analysis (CA). These statistical methodologies were applied to physicochemical, bacteriological and ecotoxicological data (with the marine bacterium Vibrio fischeri and the green alga Chlorella vulgaris) obtained with the analysis of water samples monthly collected at seven monitoring sites and during five campaigns (February, May, June, August, and September 2006). The results of some variables were assigned to water quality classes according to national guidelines. Chemical and bacteriological quality data led to classify Leça River water quality as "bad" or "very bad". PCA and CA identified monitoring sites with similar pollution pattern, giving to site 1 (located in the upstream stretch of the river) a distinct feature from all other sampling sites downstream. Ecotoxicity results corroborated this classification thus revealing differences in space and time. The present study includes not only physical, chemical and bacteriological but also ecotoxicological parameters, which broadens new perspectives in river water characterization. Moreover, the application of PCA and $\mathrm{CA}$ is very useful to optimize water quality monitoring networks, defining the minimum number of sites and their location. Thus, these tools can support appropriate management decisions.
\end{abstract}

Keywords Chlorellavulgaris · Clusteranalysis · Ecotoxicology· Principal componentanalysis Surface waterquality Vibriofischeri 


\section{Introduction}

Due to the complexity and variability of organic and inorganic compounds that may be found in natural waters, the results of physicochemical and bacteriological analyses are not sufficient to portray the impact caused by the contaminants, once they do not reveal the effects over the ecosystem (Abel 1996). Toxicity tests make possible to determine the toxic potential of a chemical agent or a complex mixture, through the evaluation of the response of living organisms (Tisler and ZargocKoncan 1999; Williams et al. 2000).

The use of different kinds of prokaryotic (e.g. Vibrio fischeri) and eukaryotic (e.g. Chlorella vulgaris) organisms in inhibition tests provides a suitable evaluation of ecotoxicity. Simple multispecies laboratory studies not only could be beneficial in the risk assessment process, but are most appropriate when a substance impacts a known key species within a food chain (Boxall et al. 2002; Selck et al. 2002).

Microtox ${ }^{\circledR}$ is a method that allows the determination of toxicity of an aqueous solution by exposing it to the luminescent bacterium Vibrio fischeri, which was used in this study. The main advantages of this method are the short time required to obtain results $(5,15$ and $30 \mathrm{~min})$, the simplicity and high reproducibility (Munkittrick et al. 1991; Argese et al. 1998; Steevens et al. 1998).

The utility of algae as a test-organism is based on its short life cycle, making it easy to study the exposure of several generations, its high growth rate, the facility to maintain cultures in the laboratory and the ability to grow in defined synthetic media (Lewis 1995). Since photoautotrophic microalgae are primary producers of essential nutrients in the ecosystem, toxicity against these organisms is considered to be of particular importance (Eguchi et al. 2004). Chlorella vulgaris, which was selected for this study, has been widely used for toxicity bioassays (Eguchi et al. 2004; Ma et al. 2004; Santos et al. 2010).

The application of different mathematical tools, such as principal component analysis (PCA) and cluster analysis (CA), allows the interpretation of complex data matrices to better understand the water quality and ecological status of the studied system (Kotti et al. 2005; Koklu et al. 2010; Ogleni and Topal 2011; Awadallah and Yousry 2012). These studies showed the ability of PCA and CA for the evaluation and interpretation of complex data sets to get better information about water quality and the design of the monitoring network for effective management of water resources.

The study here reported aims to evaluate the surface water quality of Leça River not only by means of a classical physical, chemical and bacteriological characterization but also by ecotoxicity tests to enhance the evaluation of water quality. Leça River was selected for this study because it is one of the most polluted rivers in Portugal. The application of the multivariate analysis (PCA and CA) to group sampling sites contributes to the optimization the water quality monitoring network in water courses, thus reducing analytical work and costs.

The objectives of the water framework Directive 2000/60/EC include prevention of degradation and improvement of surface and underground water bodies to achieve a good chemical and ecological status until 2015 and promote a sustainable water reuse based on a long-term protection of available water resources. Thus classification of water bodies status is mandatory to allow the definition of environmental objectives and the implementation of management programs. Within this aim, the findings of this work are not only of local interest, regarding that Leça is a very polluted river that has to be recovered, but may also be applied to other European rivers. 


\subsection{Study Area and Water Sampling}

Leça River, located in northern Portugal, flows for approximately $48 \mathrm{~km}$ from Santo Tirso district to the Atlantic Ocean. The high industrial and urban densities in the downstream stretch of the river originate very high pollution levels and therefore ichthyofauna has no relevance. This contrasts with sparsely populated, agricultural and forested areas at the upstream stretch (Ministry of Environment 1994, 2000).

Most of the pollution load is originated by textile dyeing and printing, metallurgical and mechanical and agro-food plants, some of them discharging untreated effluents into the river (Ministry of Environment 1994, 2000).

Leça River receives also the treated effluents of several wastewater treatment plants (WWTP). The most important are located in Maia: one of them treats around 21,900 $\mathrm{m}^{3} /$ day and the other receives around $760 \mathrm{~m}^{3} /$ day of urban wastewaters, both receiving domestic and industrial effluents. Sampling points located downstream from these WWTP were selected, respectively sites 2 and 4 (Fig. 1).

Sampling locations were selected to depict the water quality evolution along the river, including an unpolluted upstream reach, a critical area affected by effluent discharges and a downstream stretch.

Figure 1 shows the location of the major industrial activities, as well as the seven sampling sites selected. The respective coordinates and some details useful for a further analysis of experimental data are provided in Table 1 .

To characterize extreme weather conditions, water samples were monthly collected in five different periods, within 1 day in each month: February, May, June, August and September of 2006. Winter and autumn high rainfall periods are represented by February and September, respectively, which are usually associated to high turbidity, suspended solids concentration and

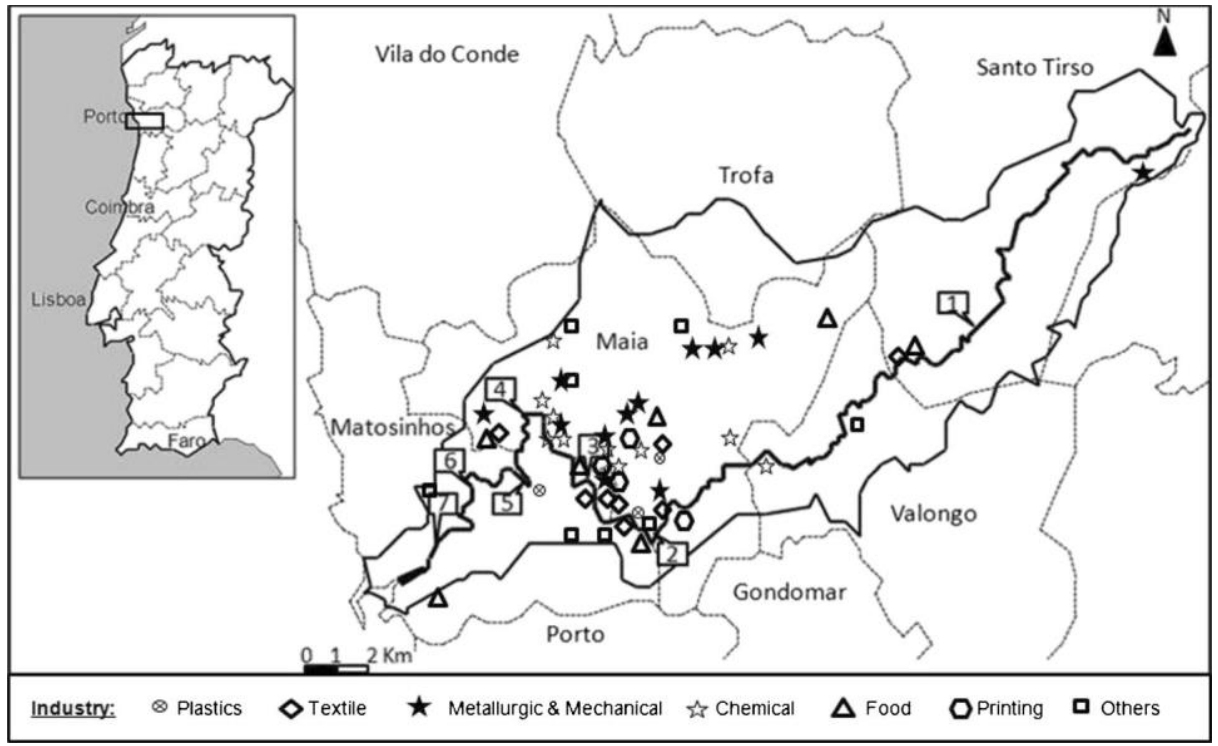

Fig. 1 Leça River basin: location of the major industrial activities and the seven selected sampling sites 
Table 1 Information about the selected sampling sites

\begin{tabular}{|c|c|c|c|}
\hline Sampling sites & Coordinates $^{\mathrm{a}}$ & Distance to river mouth $(\mathrm{km})$ & Observations \\
\hline 1 & $\begin{array}{l}41^{\circ} 15^{\prime} 41.11^{\prime \prime} \mathrm{N} \\
8^{\circ} 28^{\prime} 43.14^{\prime \prime} \mathrm{W}\end{array}$ & 36.5 & Downstream a wine cellar; mainly rural \\
\hline 2 & $\begin{array}{l}41^{\circ} 12^{\prime} 8.41^{\prime \prime} \mathrm{N} \\
8^{\circ} 35^{\prime} 47.02^{\prime \prime} \mathrm{W}\end{array}$ & 20.5 & $\begin{array}{l}\text { Downstream the discharge of a WWTP } \\
\text { (urban effluents) }\end{array}$ \\
\hline 3 & $\begin{array}{l}41^{\circ} 13^{\prime} 5.16^{\prime \prime} \mathrm{N} \\
8^{\circ} 37^{\prime} 27.02^{\prime \prime} \mathrm{W}\end{array}$ & 15.5 & Strongly industrialized area (Fig. 1) \\
\hline 4 & $\begin{array}{l}41^{\circ} 14^{\prime} 9.62^{\prime \prime} \mathrm{N} \\
8^{\circ} 38^{\prime} 49.27^{\prime \prime} \mathrm{W}\end{array}$ & 10.5 & $\begin{array}{l}\text { Downstream the discharge of a WWTP } \\
\text { (urban effluents) }\end{array}$ \\
\hline 5 & $\begin{array}{l}41^{\circ} 13^{\prime} 4.10^{\prime \prime} \mathrm{N} \\
8^{\circ} 38^{\prime} 47.68^{\prime \prime} \mathrm{W}\end{array}$ & 7.5 & Strongly industrialized area (Fig. 1) \\
\hline 6 & $\begin{array}{l}41^{\circ} 12^{\prime} 54.92^{\prime \prime} \mathrm{N} \\
8^{\circ} 40^{\prime} 2.76^{\prime \prime} \mathrm{W}\end{array}$ & 4.5 & Revitalized area with a recreational park \\
\hline 7 & $\begin{array}{l}41^{\circ} 11^{\prime} 55.28^{\prime \prime} \mathrm{N} \\
8^{\circ} 40^{\prime} 52.23^{\prime \prime} \mathrm{W}\end{array}$ & 1 & River mouth \\
\hline
\end{tabular}

${ }^{a}$ WGS 84 geographical coordinates

flow rate, leading to diluted concentration of other pollutants. The hot season (from May to August) has usually low rainfall which causes a reduction in the flow rate and therefore high concentration of most pollutants together with low dissolved oxygen, due to high temperatures. The most critical situation is achieved at the end of this period.

Most of the samples were collected from bridges, to obtain samples from running water which were representative of the river water. Grab samples were manually collected using $5 \mathrm{~L}$ plastic bottles for physicochemical analyses, $1.5 \mathrm{~L}$ plastic bottles for algal inhibition growth bioassays, $0.25 \mathrm{~L}$ borosilicate glass bottles for Microtox ${ }^{\circledR}$ toxicity bioassays and previously sterilized diving bottles for bacteriological analysis. The water samples were kept refrigerated during transportation to laboratory and were stored at $4{ }^{\circ} \mathrm{C}$ (no chemical preservatives were added).

\subsection{Physicochemical Analysis}

Temperature, $\mathrm{pH}$ and oxidation-reduction potential (HANNA Instruments model 991003), dissolved oxygen (HANNA Instruments model 9143) and conductivity (WTW, LF 330) were measured in situ. For dissolved organic carbon and metals the samples were filtered by $0.45 \mu \mathrm{m}$ pore diameter membrane filters before storage.

Water samples were analyzed in duplicate within $24 \mathrm{~h}$, according to Standard Methods (APHA et al. 2005) for turbidity (Turbiquant 3000 IR, Merck - Method 2130 B), dissolved organic carbon (DOC, Shimadzu 5000 A - Method 5310 B), biochemical oxygen demand (BOD, Crison OXI 45 - Method 5210 B), total nitrogen (spectrophotometer PYE Unicam PU 8600 UV/Vis. PHILIPS - Method 4500N C), total phosphorus (spectrophotometer PYE Unicam PU 8600 UV/Vis. PHILIPS - Method 4500 P), hardness (Method 2340C) and dissolved metals- $\mathrm{Cd}, \mathrm{Cr}, \mathrm{Cu}, \mathrm{Fe}, \mathrm{Mn}, \mathrm{Ni}, \mathrm{Pb}, \mathrm{Zn}$ (Atomic Absorption Spectrometer GBC 932 plus-Methods 3111 B and D), Hg and As (Atomic Absorption Spectrometer GBC 932 plus and GBC HG 3000-Methods $3112 \mathrm{~B}$ and 3114C). Color was measured according to the colorimetric-platinum-cobalt method 110.2 (USEPA 1983) using a PYE Unicam PU 8600 UV/ Visible PHILIPS spectrophotometer. All reagents employed were analytic grade. 
The physicochemical results were compared with the quality criteria for surface water provided in Table 2.

\subsection{Bacteriological Analysis}

All samples were analyzed (within $6 \mathrm{~h}$ after collection) in duplicate for three different concentrations, by diluting with saline medium, and filtrated by cellulose-nitrate membranes (Albeit $0.45 \mu \mathrm{m}$ pore size).

Total coliforms concentration was determined by the membrane filtration method (ISO 9308-1). Fecal coliforms concentration (thermotolerant coliforms) was determined by the membrane filtration method (ISO 9308-1). Fecal Streptococcus concentration was determined by the membrane filtration method (ISO 7899-2). The bacteriological results were compared with the quality criteria for surface water (Table 2).

\subsection{Ecotoxicological Analysis}

Bioassays were performed within $48 \mathrm{~h}$ after sampling.

The bioluminescent inhibition toxicity tests (ISO 11348) were performed using the Microtox Toxicity Analyzer Model 2055, Microbics Corporation (at present time, AZUR

Table 2 Rating parameters for surface water quality, adapted from SNIRH (2011)

\begin{tabular}{|c|c|c|c|c|c|c|}
\hline Parameter & Class & $\begin{array}{l}\text { A } \\
\text { (excellent) }\end{array}$ & B (good) & $\mathrm{C}$ (reasonable) & D (bad) & E (verybad) \\
\hline $\mathrm{pH}^{\mathrm{a}}$ & & $6.5-8.5$ & - & $6.0-9.0$ & $5.5-9.5$ & - \\
\hline Temperature & $\left({ }^{\circ} \mathrm{C}\right)$ & $\leq 20$ & $21-25$ & $26-28$ & $29-30$ & $>30$ \\
\hline Conductivity & $\left(\mu \mathrm{S} / \mathrm{cm}, 20^{\circ} \mathrm{C}\right)$ & $\leq 750$ & $751-1000$ & $1001-1500$ & $1501-3000$ & $>3000$ \\
\hline Dissolved oxygen & $(\%)$ & $\geq 90$ & $89-70$ & $69-50$ & $49-30$ & $<30$ \\
\hline BOD & $\left(\mathrm{mg} \mathrm{O}_{2} / \mathrm{L}\right)$ & $\leq 3.0$ & $3.1-5.0$ & $5.1-8.0$ & $8.1-20.0$ & $>20.0$ \\
\hline COD & $\left(\mathrm{mg} \mathrm{O}_{2} / \mathrm{L}\right)$ & $\leq 10.0$ & $10.1-20.0$ & $20.1-40.0$ & $40.1-80.0$ & $>80.0$ \\
\hline Total coliforms & $(/ 100 \mathrm{~mL})$ & $\leq 50$ & $51-5000$ & $5001-50000$ & $>50000$ & - \\
\hline Fecal coliforms & $(/ 100 \mathrm{~mL})$ & $\leq 20$ & $21-2000$ & $2001-20000$ & $>20000$ & - \\
\hline $\begin{array}{l}\text { Fecal } \\
\text { Streptococcus }\end{array}$ & $(/ 100 \mathrm{~mL})$ & $\leq 20$ & $21-2000$ & $2001-20000$ & $>20000$ & - \\
\hline Iron & $(\mathrm{mg} / \mathrm{L})$ & $\leq 0.50$ & $0.51-1.00$ & $1.01-1.50$ & $1.50-2.00$ & $>2.00$ \\
\hline Manganese & $(\mathrm{mg} / \mathrm{L})$ & $\leq 0.10$ & $0.11-0.25$ & $0.26-0.50$ & $0.51-1.00$ & $>1.00$ \\
\hline Zinc & $(\mathrm{mg} / \mathrm{L})$ & $\leq 0.30$ & $0.31-1.00$ & $1.10-5.00$ & - & $>5.00$ \\
\hline Copper & $(\mathrm{mg} / \mathrm{L})$ & $\leq 0.020$ & $0.021-0.05$ & $0.051-1.00$ & - & $>1.00$ \\
\hline Chromium & $(\mathrm{mg} / \mathrm{L})$ & $\leq 0.05$ & - & - & - & $>0.05$ \\
\hline Selenium & $(\mathrm{mg} / \mathrm{L})$ & $\leq 0.01$ & - & - & - & $>0.01$ \\
\hline Cadmium & $(\mathrm{mg} / \mathrm{L})$ & $\leq 0.0010$ & - & $\begin{array}{r}0.0011- \\
0.0050\end{array}$ & - & $>0.0050$ \\
\hline Lead & $(\mathrm{mg} / \mathrm{L})$ & $\leq 0.050$ & - & $0.051-0.100$ & - & $>0.100$ \\
\hline Mercury & $(\mathrm{mg} / \mathrm{L})$ & $\leq 0.00050$ & - & $\begin{array}{c}0.00051- \\
0.001\end{array}$ & - & $>0.001$ \\
\hline Arsenic & $(\mathrm{mg} / \mathrm{L})$ & $\leq 0.010$ & $\begin{array}{r}0.011- \\
0.050\end{array}$ & - & $0.051-0.100$ & $>0.100$ \\
\hline
\end{tabular}

\footnotetext{
${ }^{a}$ First verify if the value meets criteria A, then C and then D
} 
Environmental), and the bacterium Vibrio fischeri (strain NRRL B 11177). All samples were tested within $48 \mathrm{~h}$ after sampling following the Basic Test protocol (ISO 11348). Tested concentrations were $5.6 \%, 11.3 \%, 22.5 \%$ and $45 \%(\mathrm{v} / \mathrm{v})$. The values of $\mathrm{EC}_{50}$ and $\mathrm{EC}_{20}$ (effective concentration of the sample that causes 50 or $20 \%$ inhibition to the test-organisms, respectively) and the corresponding $95 \%$ confidence intervals were determined for 5 and 15 min of bacterial exposure.

The green algal inhibition growth tests were performed with the microalga Chlorella vulgaris according to USEPA Guideline (2002). Three replicates of each sample were tested for five different concentrations $(10 \%, 20 \%, 40 \% 60 \%$ and $80 \%)$, plus the control test. The test solutions were incubated for $72 \mathrm{~h}$, under continuous cool white fluorescent light. Agitation was manually performed twice per day and bottles were randomized. Initial and final absorbances were measured at $440 \mathrm{~nm}$ (Carvalho et al. 1995), using a Shimadzu UV-Visible spectrometer, to evaluate the growth of the algal population. The acceptability criterion considered was variability less than $20 \%$ among replicates. Shapiro-Wilk's Normality Test and Bartlett's Test for Homogeneity of Variance were performed to validate data, and Dunnett's procedure was followed (USEPA 2002). Since these assumptions were met, $\mathrm{EC}_{50}$ and $\mathrm{EC}_{20}$ were calculated by linear interpolation.

The validation of each test was performed using a reference toxicant, phenol and potassium dichromate, respectively for V.fischeri and C. vulgaris bioassays.

To simplify the results expression, toxicity units were used $\left(\mathrm{TU}_{\mathrm{xx}}=100 / \mathrm{EC}_{\mathrm{xx}}\right)$, as suggested by Wisconsin Department of Natural Resources (WDNR 2004). Expressing $\mathrm{EC}_{\mathrm{xx}}$ in percentage, $\mathrm{TU}=1$ means that the sample has no toxicity. For practical reasons, the biostimulation responses were also considered not toxic $(\mathrm{TU}=1)$, especially since Microtox® biostimulation present a negative gamma value. $\mathrm{TU}_{50}$ was used for regression models.

\subsection{Multivariate Statistical Methods}

As indicated in previous studies (Brogueira and Cabeçadas 2006; Kannel et al. 2007), Principal Component Analysis (PCA) and Cluster Analysis (CA) are multivariate statistical methods very useful to evaluate river water quality data. So, in this work, these mathematical tools were used to group sampling sites with similar water pollution patterns to select the most representative sampling sites. Both methodologies were applied using Matlab codes developed by the authors.

PCA is designed to transform the original variables into new and uncorrelated variables, called the principal components (PC), which are linear combinations of the original variables. In this study, only the PCs with eigenvalues greater than 1 (Kaiser criterion) were considered (Yidana et al. 2008; Pires et al. 2012). To evaluate the influence of each variable in the PC, varimax rotation was applied obtaining the rotated factor loadings that represent the contribution of each variable for a specific principal component.

$\mathrm{CA}$ is a multivariate technique whose primary purpose is to assemble objects based on the characteristics they possess. Hierarchical agglomerative clustering is the most common approach, which provides intuitive similarity relationships between any sample and the entire data set, and is typically illustrated by a dendrogram (tree diagram) (McKenna 2003; Varol et al. 2012). The dendrogram provides a visual summary of the clustering processes, presenting a picture of the groups and their proximity. The Euclidean distance was used as a measure of the similarity between two objects. The clustering procedure adopted was the average linkage method (Otto 1998; Pires et al. 2008).

To perform PCA and CA, data were $\mathrm{Z}$ standardized to have zero mean and unit standard deviation. 


\section{Results and Discussion}

\subsection{Physicochemical Parameters}

Physicochemical characterization of the samples is provided in Table 3 and Fig. 2 (Gomes 2007). Temperature and conductivity presented the highest values in August while dissolved oxygen (DO) presented the lowest results, due not only to higher temperatures in summer, but also to higher organics concentration associated to this dry season; following the OD variation, ORP presented the lowest values in August too; color intensity was also greater in summer; the most critical $\mathrm{pH}$ values, below 6, were obtained in summer, being the minimum 5.64 in Juneacid $\mathrm{pH}$ values are typical in the rivers of north Portugal due to its granitic soil; the highest values of turbidity were obtained in February and September, when sampling was done under intense rain.

It can be observed that site 1 shows a different behavior when compared with the other sampling locations along the river. The lowest concentrations of DOC, BOD, total nitrogen, total phosphorus and hardness were detected at the most upstream sampling site (site 1).

As concerns dissolved metals ( $\mathrm{As}, \mathrm{Cd}, \mathrm{Cr}, \mathrm{Cu}, \mathrm{Fe}, \mathrm{Hg}, \mathrm{Mn}, \mathrm{Ni}, \mathrm{Pb}$ and $\mathrm{Zn}$ ) only zinc, manganese, mercury, arsenic and iron were detected (Fig. 2). Zinc was detected in all sampling sites in February, presenting the lowest concentration at sites 1,5 and $6(0.08 \mathrm{mg} / \mathrm{L})$ and the highest at site $2(0.22 \mathrm{mg} / \mathrm{L})$ possibly due to metal plating industrial discharges, while manganese was detected only in June at site $5(0.13 \mathrm{mg} / \mathrm{L})$.

Due to the lower river flowrate, highest values were generally obtained in summer, and especially downstream from site 3 , where the chemical, metallurgic and mechanical industries are more concentrated. Although water was not polluted (Table 2) by arsenic and iron (all values are below the limits, 0.010 and $0.50 \mathrm{mg} / \mathrm{L}$, respectively), it was extremely polluted by mercury, especially in August, when all values largely exceed the limit of reasonable water quality $(0.50 \mu \mathrm{g} / \mathrm{L})$.

According to the quality criteria for surface water (Table 2), Leça River presents levels of physicochemical contamination that led to a water quality classification between "very bad" and "bad"-BOD and phosphorus exceeded the limits for minimum river water quality, according to quality standards (SNIRH 2011). Sampling site 1, at the upstream river stretch, is the less polluted site however its water quality cannot be classified as "excellent" because it exceeded the maximum mercury concentration in September (Fig. 2). The "pollution" load of industrial origin increases along the river downstream.

\subsection{Bacteriological Parameters}

The bacteriological parameters (Fig. 3) showed the lowest values in February (winter) and the highest in August (summer). The evolution of the bacteriological contamination along the river indicates: low concentrations at site 1 (upstream); very high levels of contamination at sites 2 and 3 (located downstream an urban WWTP treating urban wastewater and in a strongly industrialized and populated area, respectively); a decrease of contamination at site 4 (possibly due to the dilution of the river with the high-quality effluent of a WWTP upstream from site 4); a contamination increase at site 5; and a slight decrease at sites 6 and 7 .

Considering the bacteriological analyses, most of the values largely exceed the limits of excellent water quality, 50, 20 and 20 C.F.U./100 mL for total coliforms, fecal coliforms and fecal Streptococcus, respectively. Thus, Leça River water quality was classified as "bad" once again, except for sampling site 1 . 
Table 3 Physicochemical characteristics of water samples monthly collected (1 day in each month) in Leça River (Gomes 2007)

Sampling sites Physicochemical parameters

\begin{tabular}{|c|c|c|c|c|c|c|c|c|c|c|c|c|c|}
\hline & Month & $\begin{array}{l}\text { Temp } \\
\left({ }^{\circ} \mathrm{C}\right)\end{array}$ & $\mathrm{pH}$ & $\begin{array}{l}\text { ORP } \\
(\mathrm{mV})\end{array}$ & $\begin{array}{l}\text { Cond } \\
(\mu \mathrm{S} / \mathrm{cm})\end{array}$ & $\begin{array}{l}\mathrm{DO} \\
(\mathrm{mg} / \mathrm{L})\end{array}$ & $\begin{array}{l}\text { DOC } \\
(\mathrm{mg} / \mathrm{L})\end{array}$ & $\begin{array}{l}\mathrm{BOD} \\
\left(\mathrm{mgO}_{2} / \mathrm{L}\right)\end{array}$ & $\begin{array}{l}\text { Turb } \\
\text { (NTU) }\end{array}$ & $\begin{array}{l}\text { Color } \\
\text { (Pt-Co) }\end{array}$ & $\begin{array}{l}\text { Total N } \\
(\mathrm{mgN} / \mathrm{L})\end{array}$ & $\begin{array}{l}\text { Total P } \\
(\mathrm{mgP} / \mathrm{L})\end{array}$ & $\begin{array}{l}\text { Hardness } \\
\left(\mathrm{mgCaCO}_{3} / \mathrm{L}\right)\end{array}$ \\
\hline \multirow[t]{5}{*}{1} & February & 9.8 & 7.14 & 235 & 121 & 10.5 & 3.6 & - & 28 & 10 & 27.4 & 0.8 & 37.1 \\
\hline & May & 12.1 & 6.75 & 263 & 73 & 8.5 & 1.3 & 2.6 & 0.60 & 0 & 2.3 & $<0.1$ & 28.7 \\
\hline & June & 17.0 & 6.11 & 176 & 89 & 8.3 & 2.2 & 0.6 & 0.06 & 14 & 7.9 & 0.1 & 40.7 \\
\hline & August & 21.0 & 6.61 & 79 & 179 & 6.1 & 3.8 & 1.5 & 3.5 & 1 & 5.4 & 0.2 & 44.3 \\
\hline & September & 18.0 & 5.88 & 153 & 123 & 6.8 & 11.3 & 5.6 & 240 & 43 & 3.3 & 0.2 & 35.9 \\
\hline \multirow[t]{5}{*}{2} & February & 9.8 & 7.07 & 187 & 150 & 10.3 & 5.7 & - & 110 & 21 & 35.5 & 0.8 & 46.7 \\
\hline & May & 14.4 & 6.04 & 244 & 226 & 8.2 & 3.0 & 5.1 & 3.5 & 2 & 11.7 & 0.8 & 67.0 \\
\hline & June & 20.0 & 5.64 & 222 & 483 & 7.9 & 12.0 & 10.2 & 7.8 & 43 & 30.7 & 2.4 & 89.7 \\
\hline & August & 22.2 & 6.00 & 71 & 1,050 & 5.4 & 24.6 & 21.2 & 12 & 44 & 70.7 & 3.7 & 140.0 \\
\hline & September & 18.7 & 5.85 & 133 & 160 & 5.0 & 11.1 & 9.6 & 130 & 32 & 4.7 & 1.8 & 75.2 \\
\hline \multirow[t]{5}{*}{3} & February & 10.6 & 6.94 & 161 & 179 & 9.5 & 5.4 & - & 60 & 13 & 28.3 & 0.9 & 51.4 \\
\hline & May & 15.0 & 6.03 & 236 & 251 & 7.8 & 4.3 & 6.0 & 3.5 & 1 & 17.4 & 0.9 & 71.8 \\
\hline & June & 20.2 & 5.96 & 197 & 496 & 7.5 & 13.6 & 15.0 & 9.3 & 46 & 38.2 & 2.8 & 101.7 \\
\hline & August & 22.5 & 5.96 & 109 & 857 & 5.2 & 23.1 & 10.6 & 8.5 & 35 & 57.8 & 4.3 & 140.0 \\
\hline & September & 18.6 & 6.55 & 80 & 174 & 5.3 & 11.0 & 12.0 & 170 & 33 & 3.5 & 2.3 & 83.6 \\
\hline \multirow[t]{5}{*}{4} & February & 10.9 & 7.01 & 187 & 180 & 9.8 & 4.7 & - & 65 & 16 & 30.9 & 0.6 & 89.7 \\
\hline & May & 15.4 & 6.28 & 204 & 287 & 7.8 & 4.8 & 7.7 & 4.3 & 3 & 22.2 & 1.0 & 82.5 \\
\hline & June & 20.5 & 6.12 & 206 & 577 & 8.1 & 16.6 & 15.7 & 17 & 62 & 33.7 & 3.0 & 99.3 \\
\hline & August & 23.0 & 6.07 & 94 & 935 & 5.8 & 21.7 & 31.3 & 10 & 38 & 54.7 & 2.7 & 130.4 \\
\hline & September & 18.6 & 5.91 & 105 & 178 & 5.2 & 10.5 & 15.6 & 260 & 28 & 12.8 & 2.8 & 90.5 \\
\hline \multirow[t]{3}{*}{5} & February & 10.4 & 6.65 & 183 & 176 & 9.8 & 4.4 & - & 65 & 15 & 26.4 & 0.8 & 69.4 \\
\hline & May & 15.0 & 6.07 & 230 & 265 & 8.0 & 3.8 & 12.0 & 6.7 & 1 & 14.4 & 0.9 & 76.6 \\
\hline & June & 20.4 & 6.05 & 203 & 556 & 7.9 & 15.3 & 12.6 & 12 & 57 & 30.7 & 2.6 & 100.5 \\
\hline
\end{tabular}


Table 3 (continued)

\begin{tabular}{|c|c|c|c|c|c|c|c|c|c|c|c|c|c|}
\hline \multirow[t]{2}{*}{ Sampling sites } & \multicolumn{13}{|c|}{ Physicochemical parameters } \\
\hline & Month & $\begin{array}{l}\text { Temp } \\
\left({ }^{\circ} \mathrm{C}\right)\end{array}$ & $\mathrm{pH}$ & $\begin{array}{l}\text { ORP } \\
(\mathrm{mV})\end{array}$ & $\begin{array}{l}\text { Cond } \\
(\mu \mathrm{S} / \mathrm{cm})\end{array}$ & $\begin{array}{l}\mathrm{DO} \\
(\mathrm{mg} / \mathrm{L})\end{array}$ & $\begin{array}{l}\text { DOC } \\
(\mathrm{mg} / \mathrm{L})\end{array}$ & $\begin{array}{l}\mathrm{BOD} \\
\left(\mathrm{mgO}_{2} / \mathrm{L}\right)\end{array}$ & $\begin{array}{l}\text { Turb } \\
\text { (NTU) }\end{array}$ & $\begin{array}{l}\text { Color } \\
\text { (Pt-Co) }\end{array}$ & $\begin{array}{l}\text { Total N } \\
(\mathrm{mgN} / \mathrm{L})\end{array}$ & $\begin{array}{l}\text { Total P } \\
(\mathrm{mgP} / \mathrm{L})\end{array}$ & $\begin{array}{l}\text { Hardness } \\
\left(\mathrm{mgCaCO}_{3} / \mathrm{L}\right)\end{array}$ \\
\hline & August & 23.3 & 5.97 & 72 & 952 & 5.5 & 21.8 & 20.2 & 13 & 32 & 57.0 & 3.0 & 140.0 \\
\hline & September & 18.7 & 6.07 & 98 & 194 & 4.5 & 10.9 & 13.2 & 180 & 30 & 5.4 & 1.8 & 82.5 \\
\hline \multirow[t]{5}{*}{6} & February & 10.7 & 6.50 & 158 & 192 & 11.7 & 4.8 & - & 100 & 16 & 25.0 & 0.7 & 62.2 \\
\hline & May & 16.0 & 6.34 & 197 & 318 & 7.7 & 5.6 & 8.7 & 10 & 3 & 19.8 & 1.2 & 82.5 \\
\hline & June & 21.8 & 6.07 & 241 & 560 & 7.9 & 15.5 & 18.9 & 11 & 61 & 30.4 & 2.7 & 102.9 \\
\hline & August & 22.4 & 6.23 & 109 & 932 & 5.3 & 20.7 & 22.7 & 13 & 39 & 56.4 & 8.2 & 131.6 \\
\hline & September & 18.3 & 6.41 & 149 & 305 & 6.3 & 12.7 & 3.8 & 200 & 29 & 11.1 & 2.5 & 89.7 \\
\hline \multirow[t]{5}{*}{7} & February & 10.9 & 6.98 & 145 & 187 & 10.3 & 5.0 & - & 120 & 18 & 27.7 & 0.7 & 58.6 \\
\hline & May & 16.0 & 6.25 & 204 & 343 & 8.3 & 5.7 & 9.3 & 8.1 & 3 & 27.9 & 1.1 & 88.5 \\
\hline & June & 22.9 & 6.05 & 253 & 578 & 7.6 & 14.8 & 19.2 & 12 & 58 & 34.0 & 2.8 & 117.2 \\
\hline & August & 23.2 & 5.98 & 113 & 1,769 & 5.2 & 19.1 & 24.7 & 8.2 & 38 & 26.0 & 12.2 & 226.0 \\
\hline & September & 18.2 & 6.74 & 90 & 298 & 5.6 & 12.7 & 13.6 & 180 & 28 & 117.0 & 2.8 & 100.4 \\
\hline
\end{tabular}

-: not measured 

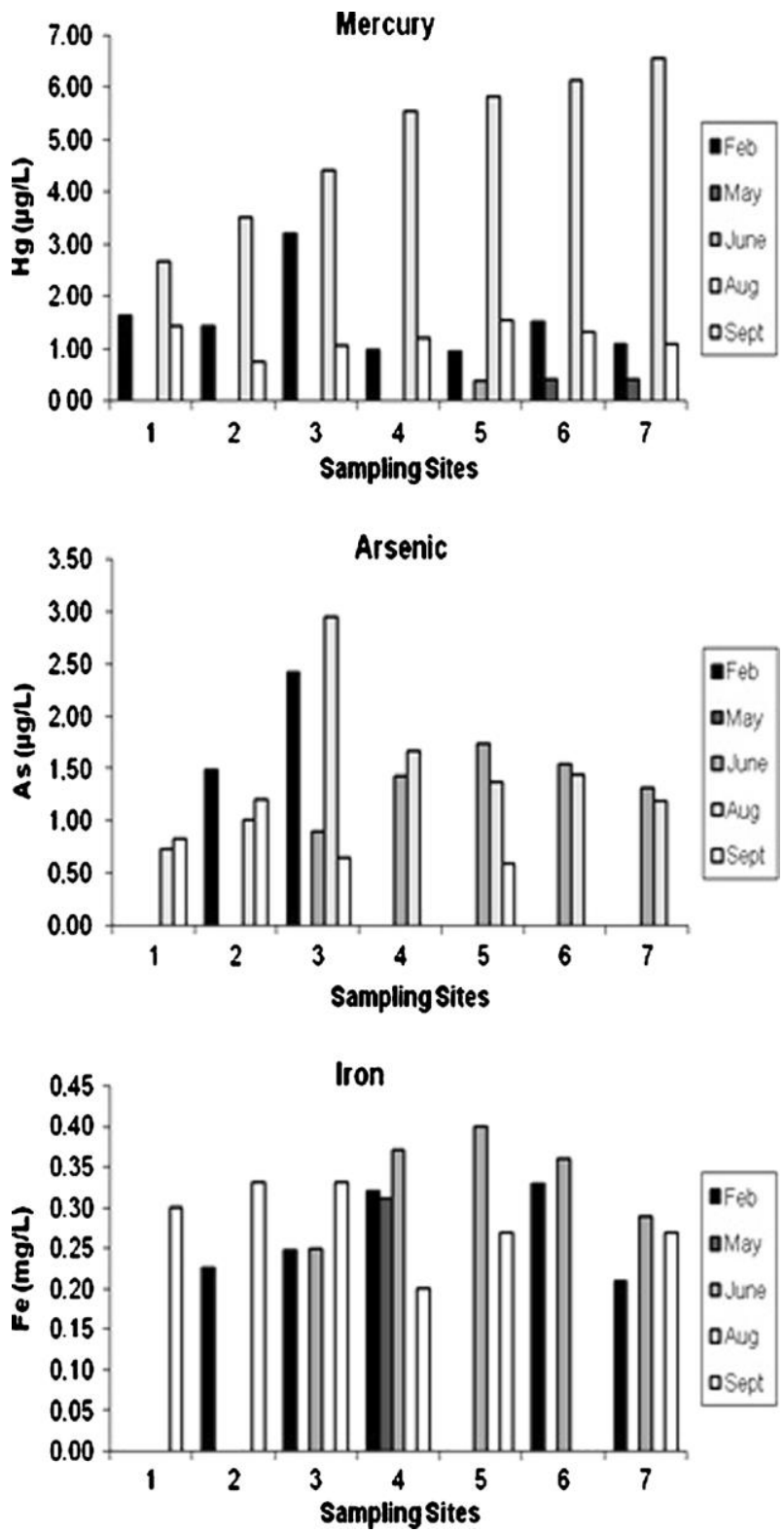

Fig. 2 Dissolved metals in Leça River water samples (detection levels: $\mathrm{Hg}<0.35 \mu \mathrm{g} / \mathrm{L}$; As $<0.6 \mu \mathrm{g} / \mathrm{L}$ and $\mathrm{Fe}<0.2 \mathrm{mg} / \mathrm{L}$ )

\subsection{Ecotoxicological Parameters}

The ecotoxicological results from inhibition of the bioluminescent bacterium Vibrio fischeri (Microtox ${ }^{\circledR}$ ) and the growth of the green alga Chlorella vulgaris are provided in Table 4 . The bacterial inhibition results shows that February was the critical month, followed by September 

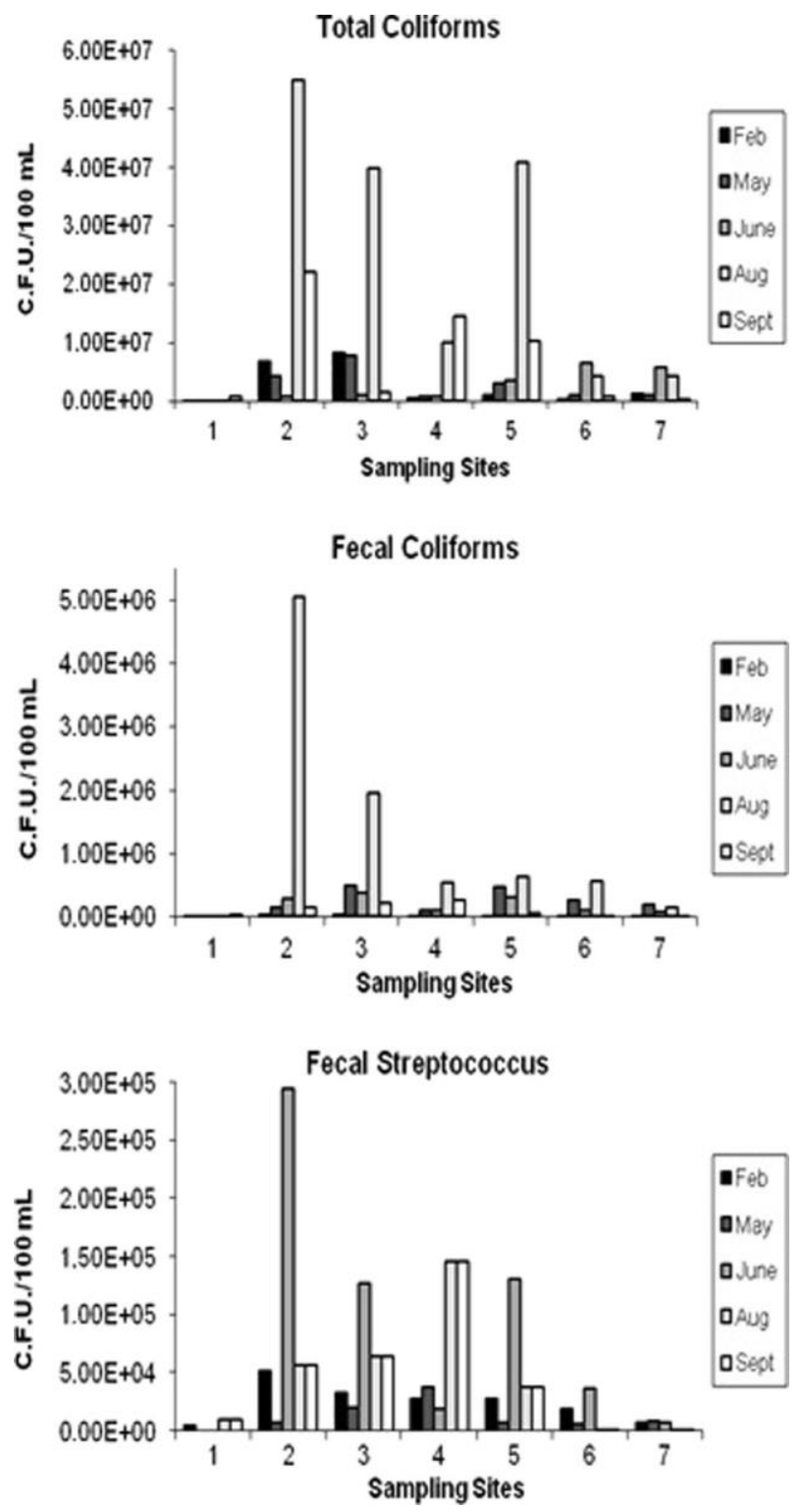

Fig. 3 Bacteriological characterization of Leça River water samples

and May, while in June and August the bioassays with Vibrio fischeri showed biostimulation responses and therefore, toxicity was not detected. No toxicity was detected at site 1 but it increases downstream, generally showing the highest values at site 3 (strongly industrialized area) and then decreasing towards the river mouth. Although not expected, in site 4 in May and in site 7 in February for $\mathrm{TU}_{20}$, the results indicate a decrease of toxicity (acclimation), which was not confirmed by the correspondent $\mathrm{TU}_{50}$ used for regression. 
Table 4 V.fischeri and C. vulgaris ecotoxicological results of Leça River water samples

\begin{tabular}{|c|c|c|c|c|c|c|c|}
\hline \multirow[t]{3}{*}{ Sampling sites } & \multirow[t]{3}{*}{ Month } & \multicolumn{4}{|c|}{ Vibrio fischeri } & \multicolumn{2}{|l|}{ Chlorella vulgaris } \\
\hline & & \multicolumn{2}{|c|}{$\mathrm{TU}_{50}=100 / \mathrm{EC}_{50}$} & \multicolumn{2}{|c|}{$\mathrm{TU}_{50}=100 / \mathrm{EC}_{50}$} & \multirow[t]{2}{*}{$\mathrm{TU}_{20}=100 / \mathrm{EC}_{20}$} & \multirow[t]{2}{*}{$\mathrm{TU}_{50}=100 / \mathrm{EC}_{50}$} \\
\hline & & $5 \mathrm{~min}$ & $15 \mathrm{~min}$ & $5 \mathrm{~min}$ & $15 \mathrm{~min}$ & & \\
\hline \multirow[t]{5}{*}{1} & February & 1 & $1^{\mathrm{a}}$ & 1.2 & $1^{\mathrm{a}}$ & 1.9 & 1 \\
\hline & May & 1 & 1 & 1 & 1 & $1^{\mathrm{a}}$ & $1^{\mathrm{a}}$ \\
\hline & June & 1 & 1 & 1 & 1 & 1.1 & 1 \\
\hline & August & $1^{\mathrm{a}}$ & $1^{\mathrm{a}}$ & $1^{\mathrm{a}}$ & $1^{\mathrm{a}}$ & $1^{\mathrm{a}}$ & $1^{\mathrm{a}}$ \\
\hline & $\begin{array}{l}\text { September } \\
10.3\end{array}$ & 1 & $1^{\mathrm{a}}$ & 2.7 & $1^{\mathrm{a}}$ & 27.8 & \\
\hline \multirow[t]{5}{*}{2} & February & 1 & 1 & 1.3 & 2.0 & 2.6 & 1 \\
\hline & May & 1.7 & 1.5 & 18.2 & 23.3 & 3.3 & 1.9 \\
\hline & June & $1^{\mathrm{a}}$ & $1^{\mathrm{a}}$ & $1^{\mathrm{a}}$ & $1^{\mathrm{a}}$ & $1.2^{\mathrm{b}}$ & $1.6^{\mathrm{b}}$ \\
\hline & August & $1^{\mathrm{a}}$ & $1^{\mathrm{a}}$ & $1^{\mathrm{a}}$ & $1^{\mathrm{a}}$ & $1^{\mathrm{a}}$ & $1^{\mathrm{a}}$ \\
\hline & September & 6.2 & 5.3 & 10.2 & 8.1 & 27.8 & 11.1 \\
\hline \multirow[t]{5}{*}{3} & February & 6.3 & 5.7 & 18.2 & 16.9 & 29.4 & 11.9 \\
\hline & May & 1 & 1.2 & 3.5 & 11.6 & 3.1 & 1.8 \\
\hline & June & 1 & 1 & 4.1 & 5.9 & $1.2^{\mathrm{b}}$ & $3.7^{\mathrm{b}}$ \\
\hline & August & 4.0 & 4.5 & 7.5 & 8.3 & 28.6 & 11.3 \\
\hline & September & 5.8 & 6.2 & 10.8 & 10.0 & 22.9 & 8.8 \\
\hline \multirow[t]{5}{*}{4} & February & 6.3 & 5.7 & 18.2 & 15.9 & 16.7 & 2.4 \\
\hline & May & 1 & 1 & 76.9 & 8.3 & $1^{\mathrm{a}}$ & $1^{\mathrm{a}}$ \\
\hline & June & $1^{\mathrm{a}}$ & $1^{\mathrm{a}}$ & $1^{\mathrm{a}}$ & $1^{\mathrm{a}}$ & $1^{\mathrm{a}}$ & $1^{\mathrm{a}}$ \\
\hline & August & $1^{\mathrm{a}}$ & $1^{\mathrm{a}}$ & $1^{\mathrm{a}}$ & $1^{\mathrm{a}}$ & 3.1 & 1 \\
\hline & September & 1 & $1^{\mathrm{a}}$ & 1 & $1^{\mathrm{a}}$ & $1^{\mathrm{a}}$ & $1^{\mathrm{a}}$ \\
\hline \multirow[t]{5}{*}{5} & February & 1.4 & 2.1 & 4.7 & 4.3 & 3.3 & 1.2 \\
\hline & May & 1 & 1 & 3.8 & 4.0 & 35.7 & 3.5 \\
\hline & June & $1^{\mathrm{a}}$ & $1^{\mathrm{a}}$ & $1^{\mathrm{a}}$ & $1^{\mathrm{a}}$ & $1^{\mathrm{a}}$ & $1^{\mathrm{a}}$ \\
\hline & August & $1^{\mathrm{a}}$ & $1^{a}$ & $1^{\mathrm{a}}$ & $1^{\mathrm{a}}$ & 2.3 & 1.6 \\
\hline & September & 3.4 & 3.4 & 6.9 & 6.5 & $1^{\mathrm{a}}$ & $1^{\mathrm{a}}$ \\
\hline \multirow[t]{5}{*}{6} & February & 1.5 & 1.7 & 4.7 & 4.7 & 2.5 & 1 \\
\hline & May & 1 & 1 & 3.8 & 4.0 & $1^{\mathrm{a}}$ & $1^{\mathrm{a}}$ \\
\hline & June & $1^{\mathrm{a}}$ & $1^{\mathrm{a}}$ & $1^{\mathrm{a}}$ & $1^{\mathrm{a}}$ & $1.2^{\mathrm{b}}$ & $2.5^{\mathrm{b}}$ \\
\hline & August & 3.1 & 3.2 & 6.5 & 5.5 & $1^{\mathrm{a}}$ & $1^{\mathrm{a}}$ \\
\hline & September & $1^{\mathrm{a}}$ & $1^{\mathrm{a}}$ & $1^{\mathrm{a}}$ & $1^{\mathrm{a}}$ & $1^{\mathrm{a}}$ & $1^{\mathrm{a}}$ \\
\hline \multirow[t]{5}{*}{7} & February & 6.3 & $1^{\mathrm{a}}$ & 18.2 & $1^{\mathrm{a}}$ & 13.9 & 1 \\
\hline & May & 1 & 1 & 1.3 & 3.1 & $1^{\mathrm{a}}$ & $1^{\mathrm{a}}$ \\
\hline & June & $1^{\mathrm{a}}$ & $1^{\mathrm{a}}$ & $1^{\mathrm{a}}$ & $1^{\mathrm{a}}$ & $1^{\mathrm{b}}$ & $1.6^{\mathrm{b}}$ \\
\hline & August & 1 & 1 & 1.2 & 1.2 & $1^{\mathrm{b}}$ & $1.6^{\mathrm{b}}$ \\
\hline & September & $1^{\mathrm{a}}$ & $1^{\mathrm{a}}$ & $1^{\mathrm{a}}$ & $1^{\mathrm{a}}$ & $1^{\mathrm{b}}$ & $1.6^{\mathrm{b}}$ \\
\hline
\end{tabular}

${ }^{\text {a }}$ Biostimulation for all concentrations tested

${ }^{\mathrm{b}}$ Toxicity decreased with the increase of tested concentration

The bioassays using Chlorella vulgaris also showed February as the critical month with inhibition results in almost all samples, followed by September; biostimulation was also 
detected especially in May, followed by August and September. In June almost all samples presented inhibition that decreased with the increase of tested concentration.

The ecotoxicological evaluation by means of mono specific bioassays, with Vibrio fischeri

and Chlorella vulgaris, integrates the effect of physicochemical and bacteriological water quality. Nevertheless, since bioassays were carried out under controlled experimental conditions, they represent a simplified situation (Hsu et al. 2007). In the river, physical factors such as temperature, flowrate, interactions among abiotic factors and biotic interrelations may also affect the toxicological response of aquatic organisms. In addition, synergistic and antagonist effects can vary at different dilutions, e.g., in concentrated samples, some substances can form micelles and some of the toxicological effects can be inhibited, whereas in more diluted samples, these substances can be more bioavailable, so their effects increase (Farré et al. 2007).

Almost no toxic effect was detected in spring and summer bioassays (May, June and August), except for sampling site 3. Oppositely, a stimulation response was observed for both test organisms. One possible explanation for this effect is the high concentration of both nitrogen and phosphorus, especially in summer, which would imply a prevalence of the stimulating effect of nutrients over the inhibiting effect of toxicants (Olguín et al. 2004). Another potential reason may be the natural algal bloom during spring and summer where a variety of photosynthetic products are excreted into the water, being used as substrates to support the growth and metabolism of bacteria (Hsu et al. 2007).

\subsection{Multivariate Analysis}

The mathematical tools PCA and CA were applied to group sampling sites with similar water pollution pattern. Concerning the analyzed metals, only the ones presenting concentrations above the detection limit ( $\mathrm{Zn}, \mathrm{Mn}, \mathrm{Hg}$, As and $\mathrm{Fe}$ ) were used in these statistical analyses. For the measurements below the detection limit, the used values were half of the correspondent limit value.

Figure 4 shows the graphical representation of PCA results according to physicochemical, bacteriological, ecotoxicological and all parameters. For physicochemical data, the first two principal components $\left(\mathrm{PC}_{1}\right.$ and $\left.\mathrm{PC}_{2}\right)$ explain $93.3 \%$ of total variance. $\mathrm{PC}_{1}$ includes important contributions of sites $2,3,4,5,6$ and 7 , while $\mathrm{PC}_{2}$ is heavily loaded by site 1 . Considering bacteriological data, three $\mathrm{PCs}$ explain $93.0 \%$ of the total variance. $\mathrm{PC}_{1}$ shows important contributions of sites 2, 3 and 5; $\mathrm{PC}_{2}$ is markedly related to sites 1 and 4; and sites 6 and 7 are significantly associated to $\mathrm{PC}_{3}$. Taking into consideration the ecotoxicological parameters, three $\mathrm{PCs}$ explain $73.3 \%$ of the total variance. $\mathrm{PC}_{1}$ has important contributions of sites 3, 4, 6 and 7; $\mathrm{PC}_{2}$ was strongly loaded by sites 2 and 5; and site 1 is significantly associated to PC 3 . Finally, considering all parameters, only two PCs were obtained, explaining $76.6 \%$ of the total variance. $\mathrm{PC}_{2}$ is associated to site 1 , while $\mathrm{PC}_{1}$ includes important contributions of the remaining sites. PCA groups the original variables (in this study, the sampling sites) according similar variation of their values, i.e. correlated variables were grouped in the same PC. The sampling sites corresponding to redundant measurements can be removed from future water quality studies or relocated to other non-monitored regions to better characterize the river water quality.

Figure 5 shows the dendrograms resulting from the application of CA to physicochemical, bacteriological, ecotoxicological and all parameters. Analyzing the different groups of parameters, the seven sampling sites can be divided in two clusters $\left(\mathrm{CL}_{1}\right.$ and $\left.\mathrm{CL}_{2}\right)$ with similar water pollution pattern. However, sites are grouped in different ways while considering physicochemical ( $\mathrm{CL}_{1}$-sites 2, 3, 4, 5,6 and 7; $\mathrm{CL}_{2}$-site 1), bacteriological ( $\mathrm{CL}_{1}$ - sites 1, 4, 6 and 7; $\mathrm{CL}_{2}$-sites 2, 3 and 5), ecotoxicological parameters $\left(\mathrm{CL}_{1}\right.$-sites 1, 2, 4, 5, 6 and 7; $\mathrm{CL}_{2}$ site 3) or all data $\left(\mathrm{CL}_{1}\right.$ - sites 2, 3, 4, 5, 6 and 7; $\mathrm{CL}_{2}-$ site 1). 
(a)

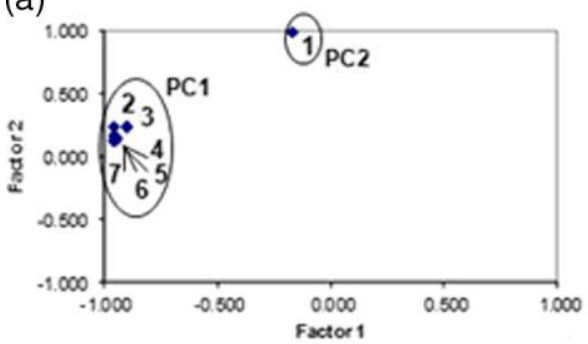

(c)

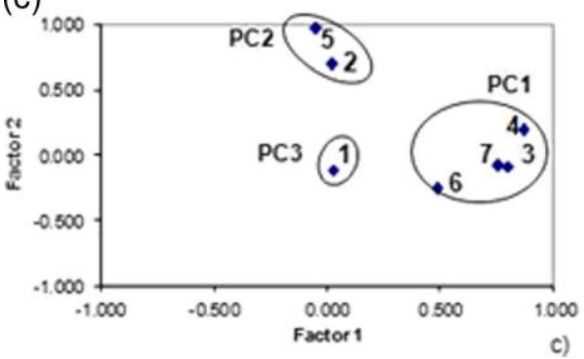

(b)

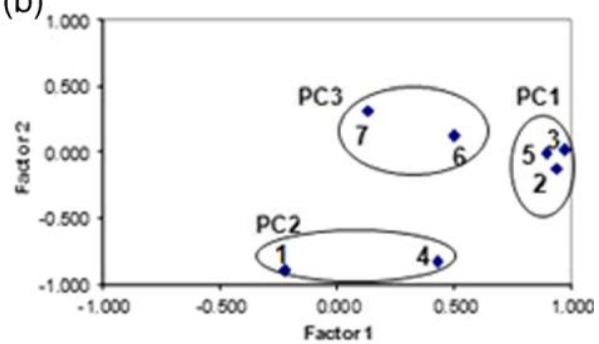

(d)

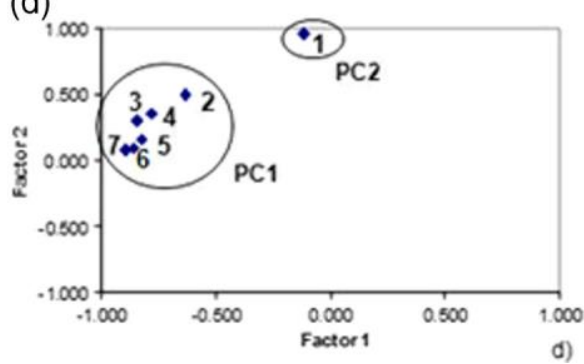

Fig. 4 Graphical representation of PCA results according to: a physicochemical parameters; b bacteriological parameters; c ecotoxicological parameters; $\mathrm{d}$ all parameters

PCA and CA, based on the physicochemical data, divided the sampling sites in a similar way: $\mathrm{PC}_{1}$ and $\mathrm{PC}_{2}$ correspond to $\mathrm{CL}_{1}$ and $\mathrm{CL}_{2}$, respectively (Figs. $4 \mathrm{a}$ and 5a). Located at the
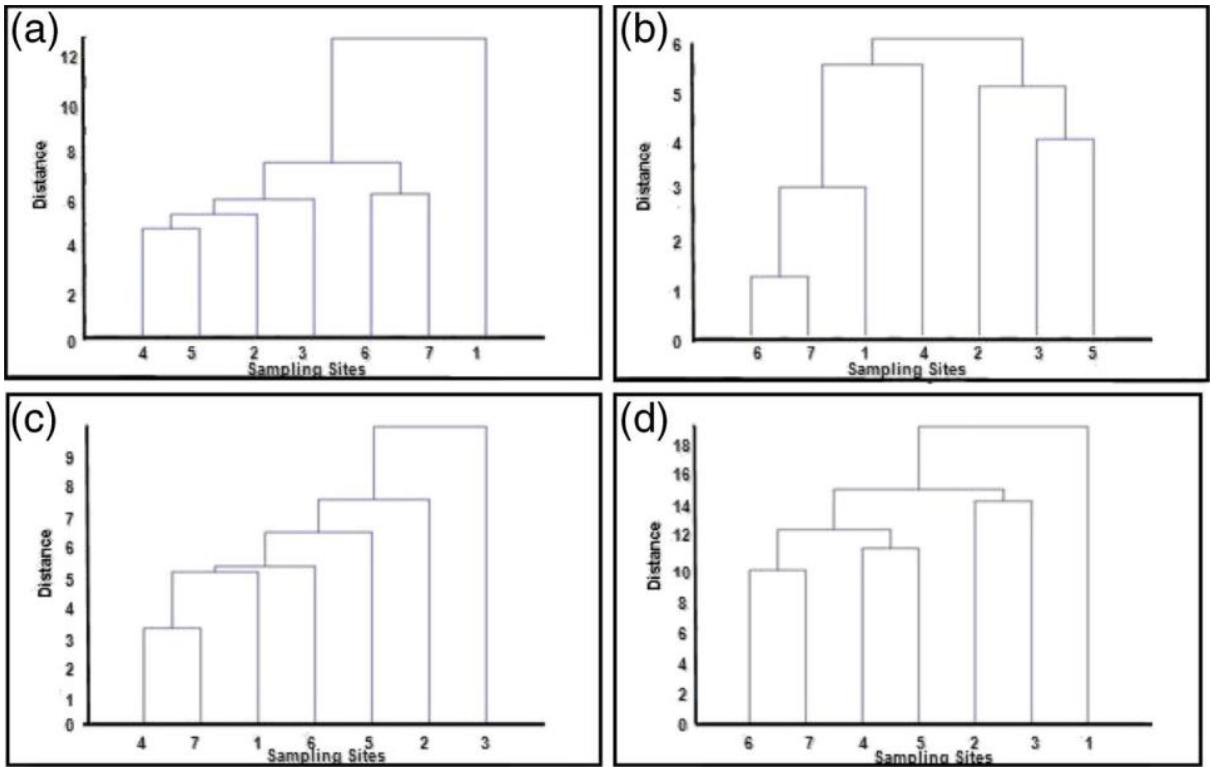

Fig. 5 Dendrograms showing clustering of sampling sites according to: a physicochemical parameters; b bacteriological parameters; $\mathrm{c}$ ecotoxicological parameters; $\mathrm{d}$ all parameters 
upstream stretch of the river, site 1 revealed unique characteristics and is different from all other sampling sites downstream.

With regard to the bacteriological data, once again PCA and $\mathrm{CA}$ results were consistent; $\mathrm{PC}_{1}$ corresponds to $\mathrm{CL}_{2}$, while $\mathrm{PC}_{2}$ and $\mathrm{PC}_{3}$ correspond to $\mathrm{CL}_{1}$ (Figs. $4 \mathrm{~b}$ and $5 \mathrm{~b}$ ). This division is supported by the bacteriological results that showed high levels of contamination at site 2 , followed by sites 3 and 5 (all located in the intermediate section of the river in a highly populated area), and relatively low levels of contamination at sites 1 (located upstream in a rural area), 4 (located after a sewage treatment plant), 6 and 7 (both located downstream, near the rivermouth).

Concerning the ecotoxicological results, PCA and CA present a slightly different division: sampling sites 2 and $5\left(\mathrm{PC}_{2}\right)$ appear close to each other in the dendrogram while sites 4, 7 and $6\left(\mathrm{PC}_{1}\right)$ show proximity according CA (Figs. $4 \mathrm{c}$ and $5 \mathrm{c}$ ). Site 3 often presents positive ecotoxicity results and therefore it was included in $\mathrm{CL}_{2}$.

PCA and $\mathrm{CA}$, in the analysis to all parameters, equally divided the sampling sites, so that $\mathrm{PC}_{1}$ and $\mathrm{PC}_{2}$ corresponded to $\mathrm{CL}_{1}$ and $\mathrm{CL}_{2}$, respectively (Figs. $4 \mathrm{~d}$ and $5 \mathrm{~d}$ ). Once again site 1 appears to have distinct features from all other sites along the river. The classification scheme obtained by CA is confirmed by PCA. The same conclusion was verified by Papaioannou et al. (2010). The application of these tools to water quality data showed that there are monitoring sites associated with the same pollution pattern, which corresponds to redundant measurements and should be moved to other locations, optimizing the water quality assessment in Leça river basin. For instance, one of the sampling sites 2 or 5, which presented redundant physicochemical, bacteriological and ecotoxicological measurements, should be eliminated or displaced. In this case, as shown in Figs. $4 c$ and 5c, the ecotoxicological parameters (Table 4) were determinant to distinguish site 3 from sites 2 and 5, meaning that the ecotoxicological analysis should be also considered if a complete characterization of water is demanded.

\section{Conclusions}

The water quality of Leça River was classified as "bad" or "very bad" due to contributions from numerous contamination sources that determine a sharp change in the physicochemical and bacteriological status in the downstream section.

Ecotoxicological tests were also performed to enhance the water quality evaluation and the results corroborated this classification, thus revealing differences in space and time. This new strategy of monitoring water quality includes physicochemical, bacteriological and ecotoxicological approaches. To group similar sampling sites, the application of PCA and CA showed that site 1, located upstream the river, presented unique characteristics, typical of "excellent" water quality, contrasting with the downstream sampling sites, where the water quality is highly affected by the intense demographic occupation and high industrialization. The results from multivariate analysis suggest redundant measurements in sampling sites 2 and 3, which should be removed or displaced to optimize the monitoring plan of this river. This integrated approach through multivariate analysis of physicochemical, bacteriological and ecotoxicological parameters may be applied to other rivers to compare their water quality. This study shows that ecotoxicological analysis must be taken into account for a complete characterization of water quality and application of PCA and CA are indispensable tools for optimizing water quality monitoring networks in any river. 
Acknowledgments J.C.M. Pires acknowledge his Post-Doctoral fellowship (SFRH/BPD/66721/2009) supported by the Portuguese Foundation for Science and Technology (FCT), POPH-QREN and FSE.

\section{References}

Abel PD (1996) Water pollution biology, 2nd edn. Taylor \& Francis, London

APHA, AWWA, WEF (2005) Standard methods for the examination of water and wastewater, 21st edn. APHA, Washington DC

Argese E, Bettiol C, Ghirardini AV, Fasalo M, Giurin G, Ghetti P (1998) Comparison of in vitro submitochondrial particle and microtox assays for determining the toxicity of organotin compounds. Environ Toxicol Chem 17(6): 1005-1012

Awadallah AG, Yousry M (2012) Identifying homogeneous water quality regions in the Nile river using multivariate statistical analysis. Water Resour Manag 26(7):2039-2055

Boxall AB, Brown CD, Barrett KL (2002) Higher-tier laboratory methods for assessing the aquatic toxicity of pesticides. Pest Manag Sci 58:637-648

Brogueira MJ, Cabeçadas G (2006) Identification of similar environmental areas in Tagus estuary by using multivariate analysis. Ecol Indic 6(3):508-515

Carvalho F, Guilhermino L, Ribeiro R, Gonçalves F, Soares AMVM (1995) METIER (modular ecotoxicity tests incorporating ecological relevance). II. Ecotoxicity of poorly water soluble compounds: concentration versus dose. Arch Environ Contam Toxicol 29(4):431-434

Directive 2000/60/EC of the European Parliament and of the Council of 23 October 2000 establishing a framework for Community action in the field of water policy. Official Journal L 327

Eguchi K, Nagase H, Ozawa M, Endoh YS, Goto K, Hirata K, Miyamoto K, Yoshimura H (2004) Evaluation of antimicrobial agents for veterinary use in the ecotoxicity test using microalgae. Chemosphere 57(11):17331738

Farré M, Martínez E, Barceló D (2007) Validation of interlaboratory studies on toxicity in water samples. TrAC Trends Anal Chem 26(4):283-292

Gomes AI (2007) Ecotoxicity evaluation in surface waters—application to the Leça River basin. In: Department of Chemical Engineering, Faculdade de Engenharia, Universidade do Porto, (Portuguese) http://repositorioaberto.up.pt/bitstream/10216/12720/2/Texto\%20integral.pdf. Accessed 17 May 2012, Porto

Hsu P, Matthäi A, Heise S, Ahlf W (2007) Seasonal variations of sediment toxicity in the rivers Dommel and Elbe. Environ Pollut 148(3):817-823

ISO 11348. Water quality-Determination of the inhibitory effect of water samples on the light emission of Vibrio fischeri (Luminescent bacteria test)

ISO 7899-2. Water quality-Detection and enumeration of intestinal enterococci - Part 2: Membrane filtration method

ISO 9308-1. Water quality-Detection and enumeration of Escherichia coli and coliform bacteria-Part 1: Membrane filtration method

Kannel PR, Lee S, Kanel SR, Khan SP (2007) Chemometric application in classification and assessment of monitoring locations of an urban river system. Anal Chim Acta 582(2):390-399

Koklu R, Sengorur B, Topal B (2010) Water quality assessment using multivariate statistical methods—a case study: Melen river system (Turkey). Water Resour Manag 24(5):959-978

Kotti ME, Vlessidis AG, Thanasoulias NC, Evmiridis NP (2005) Assessment of river water quality in Northwestern Greece. Water Resour Manag 19(1):77-94

Lewis MA (1995) Use of freshwater plants for phytotoxicity testing: a review. Environ Pollut 87(3):319-336

Ma J, Lin F, Zhang R, Yu W, Lu N (2004) Differential sensitivity of two green algae, Scenedesmus quadricauda and Chlorella vulgaris, to 14 pesticide adjuvants. Ecotoxicol Environ Saf 58(1):61-67

McKenna JE (2003) An enhanced cluster analysis program with bootstrap significance testing for ecological community analysis. Environ Model Softw 18(3):205-220

Ministry of Environment (1994) Characterization and guidelines for North's water resources planning-The Leça River basin (Portuguese)

Ministry of Environment (2000) Plan of Leça River basin (Portuguese)

Munkittrick KR, Power EA, Sergy GA (1991) The relative sensitivity of microtox, daphnid, rainbow trout, and fathead minnow acute lethality tests. Environ Toxicol Water Qual 6(1):35-62

Ogleni N, Topal B (2011) Water quality assessment of the Mudurnu River, Turkey, using biotic indices. Water Resour Manag 25(10):2487-2508 
Olguín HF, Puig A, Loez CR, Salibián A, Topallián ML, Castañe PM, Rovedatti MG (2004) An integration of water physicochemistry, algal bioassays, phytoplankton, and zooplankton for ecotoxicological assessment in a highly polluted lowland river. Water Air Soil Pollut 155(1-4):355-381

Otto M (1998) Multivariate methods. In: Kellner R, Mermet JM, Otto M, Widmer HM (eds) Analytical chemistry. Wiley-VCH, Weinheim, p 916

Papaioannou A, Mavridou A, Hadjichristodoulou C, Papastergiou P, Pappa O, Dovriki E, Rigas I (2010) Application of multivariate statistical methods for groundwater physicochemical and biological quality assessment in the context of public health. Environ Monit Assess 170(1-4):87-97

Pires JCM, Sousa SIV, Pereira MC, Alvim-Ferraz MCM, Martins FG (2008) Management of air quality monitoring using principal component and cluster analysis-part $\mathrm{I}: \mathrm{SO}_{2}$ and $\mathrm{PM}_{10}$. Atmos Environ $42(6)$ : 1249-1260

Pires JCM, Alvim-Ferraz MCM, Pereira MC, Martins FG (2012) Comparison of several linear statistic models to predict tropospheric ozone concentrations. J Stat Comput Simul 82:183-192

Santos LHMLM, Araújo AN, Fachini A, Pena A, Delerue-Matos C, Montenegro MCBSM (2010) Ecotoxicological aspects related to the presence of pharmaceuticals in the aquatic environment. $\mathrm{J}$ Hazard Mater 175(1-3):45-95

Selck H, Riemann B, Christoffersen K, Forbes VE, Gustavson K, Hansen BW, Jacobsen JA, Kusk OK, Petersen S (2002) Comparing sensitivity of ecotoxicological effect endpoints between laboratory and field. Ecotoxicol Environ Saf 52(2):97-112

SNIRH - Sistema Nacional de Informação de Recursos Hídricos - National System of information about water resources (2011) Classification of surface water courses in accordance with their quality for multiple usages http://www.snirh.pt/snirh/_dadossintese/qualidadeanuario/boletim/tabela_classes.php. Accessed 8 May 2011 (Portuguese)

Steevens JA, Vansal SS, Kallies KW, Knight SS, Cooper CM, Benson WH (1998) Toxicological evaluation of constructed wetland habitat sediments utilizing Hyalella azteca 10-day sediment toxicity test and bacterial bioluminescence. Chemosphere 36(15):3167-3180

Tisler T, Zargoc-Koncan J (1999) Toxicity evaluation of wastewater from the pharmaceutical industry to aquatic organisms. Water Sci Technol 39(10-11):71-76

USEPA - United States Environmental Protection Agency (1983) Methods for Chemical Analysis of Water and Wastes - Method 110.2, EPA/600/4-79-020. USEPA

USEPA - United States Environmental Protection Agency (2002) Short-term methods for estimating the chronic toxicity of effluents and receiving waters to freshwater organisms (fourth edition) - EPA-821-R-02-013. USEPA, Washington DC

Varol M, Gökot B, Bekleyen A, Şen B (2012) Water quality assessment and apportionment of pollution sources of Tigris River (Turkey) using multivariate statistical techniques—a case study. River Res Appl 28(9):13251593

WDNR - Wisconsin Department of Natural Resources (2004) State of Wisconsin aquatic life toxicity testing methods manual, 2nd edn. Dept. of Natural Resources, Bureau of Watershed Management, Madison

Williams PL, James RC, Roberts SM (2000) Principles of toxicology—environmental and industrial application, 2nd edn. Wiley, New York

Yidana SM, Ophori D, Banoeng-Yakubo B (2008) A multivariate statistical analysis of surface water chemistry data— the Ankobra Basin, Ghana. J Environ Manag 86(1):80-87 